Determination of Antimicrobial, Antioxidant and Antibiofilm Activity of Some Alyssum L. Species in Anatolian Flora

\author{
Vedat TOZYILMAZ1, Yusuf CEYLAN², Ali Savaş BÜLBÜL ${ }^{3}$ \\ ${ }^{1}$ Bartın University, Institute of Science, Department of Biology, Bartın, TURKEY, ${ }^{2}$ Bartın University, Faculty of Science, Department of \\ Molecular Biology and Genetics, Bartın, TURKEY, ${ }^{3}$ Kahramanmaraş Sütçü İmam University, Faculty of Science and Letters, Department of \\ Biology, Kahramanmaraş, TURKEY \\ ${ }^{1}$ https://orcid.org/0000-0003-0799-0089, ${ }^{2}$ https://orcid.org/0000-0001-8186-7252, ${ }^{3}$ https://orcid.org/0000-0002-2200-7348 \\ $\varangle$ : asavasbulbul@gmail.com
}

\begin{abstract}
The Alyssum L. genus which is spread in the Eastern Mediterranean is known by the public as 'Rabid weed' or 'Kevke'. Many of these species are seen as a way to prevent disasters such as erosion, both due to drought resistance and low soil selectivity. Also Alyssum known as 'Tooth weed', it has been used to reduce tooth sore, bladder stones and spasm. In this study, in order to examine antibacterial and antifungal activities, extracts obtained from three naturally growing plants (Alyssum caricum T.R.Dudley and Hub.-Mor., Alyssum discolor T.R.Dudley and Hub.-Mor. and Alyssum sibiricum Willd.) in Turkey were examined on seventeen bacteria and two fungal strains by disc diffusion method. In addition, antimicrobial activity was supported by the Minimum Inhibition Concentration (MIC) and Minimum Bactericidal Concentration (MBC) method. DPPH (2,2-diphenyl-1picrilhydrazyl) method was used to investigate the antioxidant activities of plant extracts, and crystal violet binding method was used to prevent biofilm formation. As a result, $A$. caricum ethanol extract showed the best effects in antimicrobial activities. None of plants were effective against fungi. $A$. sibiricum shows the best activity in antibiofilm activity and $A$. caricum was showed the best result in antioxidant activity.
\end{abstract}

Araştırma Makalesi

Makale Tarihçesi
Geliş Tarihi $\quad: 21.10 .2020$
Kabul Tarihi $\quad: 03.12 .2020$

Anahtar Kelimeler

Alyssum discolor

Alyssum caricum

Alyssum sibiricum

Antimicrobial activity

Antioxidant

\title{
Anadolu Florasına Ait Bazı Alyssum L. Türlerinin Antimikrobiyal, Antioksidan ve Antibiyofilm
} Aktivitesinin Belirlenmesi

\section{ÖZET}

Doğu Akdeniz'de yayılış gösteren Alyssum L. cinsi, halk tarafindan 'Kuduz otu' veya 'Kevke' olarak bilinir. Alyssum türlerinin çoğu kuraklığa karşı dayanıklı olması ve toprak seçimlerinin olmaması sebebi ile erozyon gibi felaketleri önlemede önemlidir. Ayrıca Alyssum diş otu olarak bilinmekte olup diş ağrılarında, spazm ve mesane taşlarını düşürmede kullanılan bir bitkidir. $\mathrm{Bu}$ çalışmada, antibakteriyel ve antifungal aktiviteleri incelemek için ülkemizde doğal olarak yetişen üç bitkiden (Alyssum caricum T.R.Dudley ve Hub.-Mor., Alyssum discolor T.R.Dudley ve Hub.-Mor. ve Alyssum sibiricum Willd.) elde edilen ekstraktlar, disk difüzyon yöntemi ile on yedi bakteri ve iki mantar suşu üzerinde incelenmiştir. Ayrıca, antimikrobiyal aktivite Minimum İnhibisyon Konsantrasyonu (MIC) ve Minimum Bakterisidal Konsantrasyonu (MBC) yöntemi ile desteklenmiştir. Bitki ekstraktlarının antioksidan aktivitelerini araştırmak için DPPH (2,2-difenil-1-pikrilhidrazil) yöntemi, biyofilm oluşumunu önlemek için ise kristal viyole bağlama yöntemi kullanılmıştır. Sonuç olarak, antimikrobiyal çalışmasında en iyi sonucu $A$. caricum etanol ekstraktı gösterdi. Bitkilerin hiçbiri funguslara karşı etki gösteremedi. Antibiyofilm çalışmasında en iyi sonucu $A$. sibiricum gösterirken antioksidan çalışmasında ise en iyi aktiviteyi $A$. caricum ekstraktı gösterdiği tespit edildi.

\section{Research Article}

$\begin{array}{ll}\text { Article History } \\ \text { Received } & : 21.10 .2020 \\ \text { Accepted } & : 03.12 .2020\end{array}$

\section{Keywords \\ Alyssum discolor \\ Alyssum caricum \\ Alyssum sibiricum \\ Antimikrobiyal aktivite \\ Antioksidant}



To Cite: $\quad$ Tozyılmaz V, Ceylan Y, Bülbül AS 2021. Determination of Antimicrobial, Antioxidant and Antibiofilm Activity of Some Alyssum L. Species in Anatolian Flora. KSU J. Agric Nat 24 (4): 715-724. DOIः 10.18016/ ksutarimdoga. vi.814167.

\section{INTRODUCTION}

Turkey, Asia, Europe and Africa are rich areas in terms of plant flora due to their location. Generally plant species are abundant in phyto-geographical areas such as Iran-Turanian, Euro-Siberian and Mediterranean (Bülbül et al., 2018). Some Medicinal plants are used to treat living being and have active substances obtained from their certain parts (Yaldiz and Kulak, 2014). Previous studies by World Health Organization (WHO) indicated that there were about 20.000 medicinal plants (Ulgen et al., 2020). The plants used in treatment have attracted the attention of microbiologists over time and studies on the antimicrobial activities of plants have begun to intensify (Erdogrul, 2002; Altuner and Çetin, 2018; Bülbül et al., 2018). Medicines obtained from plants are used in the treatment of diseases caused by microorganisms. In research on plants, by determining the chemical composition of plants and dosage level of treatment of diseases depends on the resolution of the antimicrobial mechanism (Erdoğan and Everest, 2012). Antimicrobial research was accelerated with the discovery of penicillin and antibiotics was started to be produced from microorganisms (Shinji, 1993; Iwu et al., 1999).

Biofilms are microorganism communities where bacteria live on a damp surface and live-in harmony with each other in the extracellular matrix (Ceyhan, 2008). Organic molecules like proteins, have a role in the binding of bacteria to the surface. Furthermore, some of them lead to biofilm formation in the presence of extracellular polymeric structure (Tozyllmaz et al., 2020). The biofilm community can be found in many suitable areas such as wood, glass, tissue, plastic (Kokare et al., 2009). Microorganisms provide to communicate with chemical signals after they are attached to a surface (Taga and Bassler, 2003; March and Bentley, 2004). With the formation of biofilms, resistance of bacteria against antibiotics started to increase and researchers righted to find new alternative methods against antibiotic resistance of bacteria (Ceyhan, 2008). It is very important for scientists to work on the characterization of new antimicrobial agents in order to eliminate bacteria resistant to antimicrobial agents used for commercial purposes (Altuner et al., 2018).

Brassicaceae family is ranked on the top for the United States with a total 616 species. including 148 endemic species, while Turkey is ranked the second with a total 606 species, including 226 endemic species (AlShehbaz et al., 2007; Mutlu, 2012). While the family contains cultural products such as radish, cabbage, cress and mustard it also contains ornamental plants such as gillyflower, venus (Couvreur et al., 2010).
Belonging to Brassicaceae family, Alyssum L. genus is among the largest with consisting of 107 species and subspecies for flora of Turkey (Babaoğlu et al., 2006). Brassicaceae family is rich in antioxidant compounds, including polyphenols, owing to its beneficial health effects, and contains medically important components in terms of showing anticancer and antioxidant activities (Cartea, 2011). Therefore, directly consuming products or vegetables that contain important health-related ingredients provides protection against many common diseases (Duthie et al., 2000; Pandey and Rizvi, 2009; Avato and Argentieri, 2015).

The aim of this study was to contribute to the literature by obtaining extracts from the above-ground parts of the $A$. caricum, $A$. discolor and $A$. sibiricum in Anatolian flora and examining their antibacterial, antifungal, antibiofilm activities and antioxidant capacities on 17 different bacteria and 2 different fungus strains. It was aimed to provide guidance in the medical and industrial plants used in the flora of Turkey as well as in the world.

\section{MATERIAL and METHOD}

\section{Plant Material}

Alyssum caricum T.R. Dudley and Hub.-Mor., Alyssum discolor T.R. Dudley an Hub.-Mor. and Alyssum sibiricum Willd. plants which are grown naturally in Turkey and used in this study, collected by Metin Armağan from various locations of Anatolia. A list of taxa and full voucher data is provided in Table 1 . The above-ground parts of the plants were washed in tap water and dried in a cool and moisture-free condition and made ready for grinding.

\section{Extraction}

Soxhlet device was used for extraction. Aboveground parts of all Alyssum species were crushed by means of liquid nitrogen and ground. Each milled plant sample and solvent were placed in the soxhlet device. Extraction was performed at $55^{\circ} \mathrm{C}$ for 8 hours. At the end of the period, the plant extract dissolved in ethanol was kept in the evaporator for 30 minutes at $40^{\circ} \mathrm{C}$ to remove it from the solvent. The plant extract dissolved in dimethyl sulfoxide (DMSO) and made ready for use.

\section{Determination Antimicrobial Activity}

Test microorganisms and culture medium

In order to investigate the antibacterial and antifungal activities of the plant extracts preparated after extraction process, seventeen bacteria (Salmonella kentucky, Salmonella enteritidis ATCC 13075, Staphylococcus aureus ATCC 25923, Staphylococcus 
epidermidis DSMZ 20044, Listeria monocytogenes, Listeria innocua, Bacillus subtilis DSMZ 1971, Enterobacter aerogenes ATCC 13048, Escherichia coli ATCC 25922, Klebsiella pneumoniae, Enterococcus faecium, Enterococcus faecalis ATCC 29212, Enterococcus durans, Pseudomonas aeruginosa DSMZ 50071, Pseudomonas fluorescens, Salmonella typhimurium, Salmonella infantis) and two fungi
(Candida albicans DSMZ 1386, Candida albicans) strains were activated on Luria-Bertani (LB) broth medium. Furthermore, LB broth medium was also used for minimum inhibition concentration (MIC) determination. Nutrient Agar (NA) was used for the development of bacterial strains and minimum bactericidal concentration (MBC), while Sabouraud Dextrose Agar (SDA) was used for fungi development.

Table 1. Collection data of Alyssum L. species.

Tablo 1. Alyssum L. türlerinin toplanma verileri.

\begin{tabular}{|c|c|c|c|c|c|c|c|}
\hline 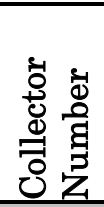 & 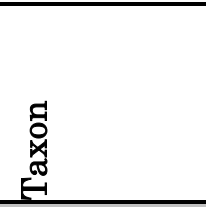 & 웜 & 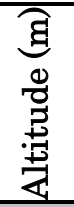 & 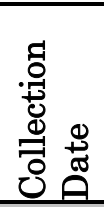 & 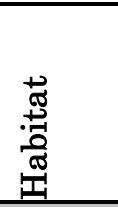 & 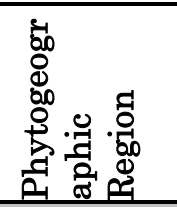 & 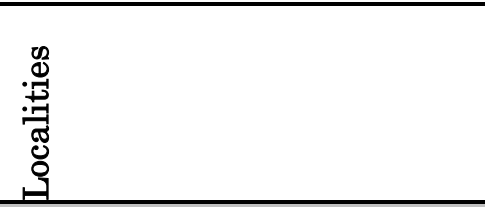 \\
\hline $\begin{array}{l}\text { A. } \\
7356\end{array}$ & A. caricum & $\begin{array}{lll}36^{\circ} & 59^{\prime} & 32.4^{\prime \prime} \mathrm{N} \\
28^{\circ} & 39^{\prime} & 15.3^{\prime \prime} \mathrm{E}\end{array}$ & 7 & 2017 & $\begin{array}{l}\text { Rocky } \\
\text { area }\end{array}$ & $\begin{array}{l}\text { Eastern } \\
\text { mediterra } \\
\text { nean }\end{array}$ & $\begin{array}{l}\text { Muğla: Köyceğiz, west of } \\
\text { Toparlar }\end{array}$ \\
\hline $\begin{array}{l}\text { A. } \\
7443\end{array}$ & A.discolor & $\begin{array}{l}36^{\circ} 52^{\prime} \quad 25.8^{\prime \prime} \mathrm{N} \\
28^{\circ} 16^{\prime} 29.6^{\prime \prime} \mathrm{E}\end{array}$ & 81 & 2017 & Step & $\begin{array}{l}\text { Eastern } \\
\text { mediterra } \\
\text { nean } \\
\text { endemic }\end{array}$ & $\begin{array}{l}\text { Muğla: Marmaris, } \\
\text { neighborhood, } \\
\text { highway exit }\end{array}$ \\
\hline $\begin{array}{l}\text { A. } \\
7353\end{array}$ & A.sibiricum & 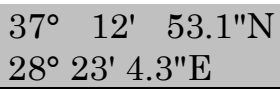 & 736 & 2017 & $\begin{array}{l}\text { Rocky } \\
\text { area }\end{array}$ & -------- & $\begin{array}{l}\text { Muğla: Center, } \\
\text { Karşıyakaneighborhood }\end{array}$ \\
\hline
\end{tabular}

\section{Determination of disc diffusion method}

Disk diffusion susceptibility test of Kirby and Bauer was used to determine the antibacterial activities of plant extracts (Dağcı and Dığrak, 2005). The dry extracts of the plants were dissolved in DMSO and three different concentrations $(200 \mathrm{mg} / \mathrm{ml}, 100 \mathrm{mg} / \mathrm{ml}$ and $50 \mathrm{mg} / \mathrm{ml}$ ) were prepared under sterile conditions. The prepared concentrations were absorbed into sterile discs. Furthermore, Tetracycline (TE 30) standard antibiotic disk was used for positive control. The test microorganisms were activated in LB broth medium for 16 -18 hours and prepared a dilution of $1.5 \times 10^{8}$ cell $/ \mathrm{ml}$ with $0.5 \mathrm{McF}$ arland turbidity. Microorganisms were cultured in the sterile petri dishes involved NA agar for bacteria and SDA agar for fungi. After a while, discs with extract placed in petri dishes properly. Bacteria were incubated at $37^{\circ} \mathrm{C}$ for $16-18$ hours and fungi were incubated at $25^{\circ} \mathrm{C}$ for $24-48$ hours and the end of time, zones diameters of the inhibitions around the discs were measured. This study was replicated three times for each of the three plants and the arithmetic mean of the results were measured in millimeters.

Determination minimum inhibition concentration (MIC)

The MIC values of the extracts were determined using the Microwell Dilution method specified by Sahin et al. (2003). Microorganisms were grown according to McFarland 0.5 turbidity. Sterile LB broth was added into all wells and $200 \mathrm{mg} / \mathrm{mL}$ plant extracts were diluted in an equal volume $(200-6,25 \mathrm{mg} / \mathrm{ml})$ and added into all wells. In addition, seventeen of different strains of microorganisms were inoculated in each well. Moreover, positive and negative control wells were prepared were comparison of absorbance values and control of the medium. Finally, microplates were incubated at $37^{\circ} \mathrm{C}$ for 16 hours, and the absorbance values of the samples were evaluated by measuring against the positive control at $600 \mathrm{~nm}$ in the spectrophotometer to determine the lowest concentration that the plant extracts inhibit the microorganism.

\section{Determination minimum bactericidal concentration (MBC)}

After obtaining the MIC results, MBC results were obtained against bacterial strains of plant extracts In the MIC results, wells that bacteria could not reproduce were determined. Samples taken from these wells cultivated on NA and incubated during for 18-24 hours at $37^{\circ} \mathrm{C}$.

\section{Determination Antibiofilm Activity}

Biofilms means the community living in a polysaccharide layer on the surface where microorganisms adhere (Tozyllmaz and Bulbul, 2018). Antibiofilm activities the prepared were determined using the method described by Atalan et al. (2020). Firstly, after the MIC results obtained in antimicrobial activity, the bacterial solutions in the microplate were incubated for an additional 24 hours at $37^{\circ} \mathrm{C}$. After the 
incubation, the microplate wells were completely drained, washed with distilled water and allowed to dry at room temperature. Then, $130 \mu \mathrm{l}$ of $95 \%$ methanol was added to the wells and left for 15 minutes. At the end of the time, the wells were emptied and allowed to dry. Following by this, $125 \mu \mathrm{l}$ of a $0.1 \%$ crystal violet solution was placed in the wells and allowed to incubated at room temperature for 10 minutes. Thenmicroplate was washed again with distilled water and allowed to dry. It was placed in $33 \%$ glacial acetic acid solution for gram positive bacteria and $95 \%$ ethanol solution for gram negative bacteria and incubated under room conditions for 15 minutes. At the end of the period, microplates were measured at $600 \mathrm{~nm}$ on a spectrophotometer. All these procedures were also performed for the positive control and the percentage reduction of biofilm inhibition was calculated by comparing the data optained from the positive control in the evaluation of the antibiofilm activity of the plant extracts against bacteria.

\% Decrease: (1- $(\mathrm{T} / \mathrm{C}) \times 100$ was made according to the formula. According to this formula;

$\mathrm{C}$ : Positive control

$\mathrm{T}$ : Test

\section{Determination of Antioxidant Activity}

DPPH (2,2-diphenyl-1-picrylhydrazyl) is a commercially produced nitrogen radical (Huang et al., 2005). DPPH method is frequently used to measure the antioxidant activity of extracts obtained from nature (Mot et al., 2011). The DPPH radical sweep stage used in the study was carried out according to the method of Blois (Blois, 1958). Dilute concentrations of plant extracts $(12.5-0.39 \mathrm{mg} / \mathrm{ml})$ and diluted concentrations of ascorbic acid solution $(12.5-0.39 \mathrm{mg} / \mathrm{ml})$ were mixed well by adding $1 / 4$ of $0.1 \mathrm{mM}$ DPPH solution. $1 / 4$ of 0.1 $\mathrm{mM}$ DPPH solution and ethanol was added for the sample control. Then, the absorbance values were measured with a spectrophotometer at a wavelength of $517 \mathrm{~nm}$ for 30 minutes under dark room conditions. The standard material (ascorbic acid) used and the DPPH solution were prepared daily. The DPPH radical scavenging activity of extracts and standard supstance concentrations was calculated by the following formula;

\% DPPH scavenging activity: $((\mathrm{C}-\mathrm{T}) / \mathrm{C}) \mathrm{x} 100$ was made according to the formula. According to this formula;

C: Control absorbance

$\mathrm{T}$ : Test absorbance

Concentrations of standard substances and plant extracts that inhibition the DPPH radical by $50 \%$ are defined as EC50 (Effective Concentration). Three parallel repetitions of each concentration were made plotted graphs according to the measurement results.

\section{RESULT}

\section{Disk Diffusion Results}

In Table 2 shows the antimicrobial activities of Alyssum species and standard antibiotics studied by disc diffusion method. Accordingly, determined it does not show inhibition zone against the strains $B$. subtilis DSMZ 1971, C. albicans, C. albicans DSMZ 1386, E. aerogenes ATCC 13048, E. faecalis ATCC 29212, L. monocytogenes and $P$. fluorescens which at three concentrations $(200,100$ and $50 \mathrm{mg} / \mathrm{ml})$ for three plant species.

\section{MIC and MBC Results}

According to the MIC and MBC results shown in Table 3 , it was observed that three plant extracts at the specified concentrations showed antimicrobial activity against 17 applied strains of bacteria.

Alyssum caricum extract had a minimum inhibitory effect against $E$. coli ATCC 25922 bacterial strains (MIC), while a minimum inhibitory effect against other bacterial strains at a concentration of $100 \mathrm{mg} / \mathrm{ml}$. In addition, $A$. caricum extract was found to have the lowest bactericidal concentration that inhibits bacterial strains at a concentration of $100 \mathrm{mg} / \mathrm{ml}$ and $200 \mathrm{mg} / \mathrm{ml}$. Alyssum discolor extract showed minimal inhibition against the Listeria innocua bacterial strain at a concentration of $100 \mathrm{mg} / \mathrm{ml}$, while it showed a minimal inhibitory effect at the other bacterial strains at a concentration of $50 \mathrm{mg} / \mathrm{ml}$ (Figure 1). In addition, It was also found that extract had the lowest bactericidal concentration, which inhibited all bacterial strains at a concentration of $100 \mathrm{mg} / \mathrm{ml}$. Alyssum sibiricum extract shows minimum inhibition against $E$. durans, $E$. faecium, $K$. pneumoniae, $P$. fluorescens bacterial strains at a concentration of 100 $\mathrm{mg} / \mathrm{ml}$, while it showed minimum inhibitory effect against other bacterial strains at a concentration of 50 $\mathrm{mg} / \mathrm{ml}$. In addition, at concentration $200 \mathrm{mg} / \mathrm{ml}, A$. sibiricum extract showed the lowest bactericidal concentration that inhibited $P$. aeruginosa DSMZ 50071 and $E$. durans bacterial strains, while $50 \mathrm{mg} / \mathrm{ml}$ against $B$. subtilis DSMZ 1971 and $E$. aerogenes ATCC 13048 bacterial strains and it was found to have the lowest bactericidal concentration at $100 \mathrm{mg} / \mathrm{ml}$ against other microorganisms.

\section{Antibiofilm Results}

The effects of three plant extracts on biofilm formation of test microorganisms were investigated, as shown in Table 4. Accordingly, it was determined that Alyssum caricum extract at $50 \mathrm{mg} / \mathrm{ml}$ concentration inhibited biofilm formation of Enterococcus faecium and Pseudomonas aeruginosa DSMZ 50071 strains by $12,6 \%$ but did not inhibite biofilm formation of other bacterial strains. Similarly, when the effects of Alyssum discolor extract on the biofilm formation of 
the test microorganisms were examined, no antibiofilm activity was observed against the bacteria tested in all three concentrations. When antibiofilm activity of Alyssum sibiricum extract was tested against test microorganisms, it was observed that biofilm formation was usually inhibited at concentrations of
$100 \mathrm{mg} / \mathrm{ml}$ and $50 \mathrm{mg} / \mathrm{ml}$. However, Enterobacter aerogenes ATCC 13048 observed no antibiofilm activity at all three concentrations against Enterobacter faecium and Listeria monocytogenes bacterial strains.

Table 2. Antimicrobial zone measurements ( $\mathrm{mm}$ ) of Alyssum L. species.

Tablo 2. Alyssum L. türlerinin antimikrobiyal zon ölçümleri (mm).

\begin{tabular}{|c|c|c|c|c|c|c|c|c|c|c|}
\hline Species & \multicolumn{3}{|c|}{ Alyssumcaricum } & \multicolumn{3}{|c|}{ Alyssumdiscolor } & \multicolumn{3}{|c|}{ Alyssum sibiricum } & (+) Control \\
\hline Microorganisms & 200 & 100 & 50 & 200 & 100 & 50 & 200 & 100 & 50 & TE30 mg/ml \\
\hline B. subtilis DSMZ 1971 & - & - & - & - & - & - & - & - & - & 28 \\
\hline C. albicans & - & - & - & - & - & - & - & - & - & 14 \\
\hline C. albicans DSMZ 1386 & - & - & - & - & - & - & - & - & - & 14 \\
\hline E. aerogenes ATCC 13048 & - & - & - & - & - & - & - & - & - & 17 \\
\hline E. durans & 4 & 2 & 2 & - & - & - & - & - & - & 16 \\
\hline E. faecalis ATCC 29212 & - & - & - & - & - & - & - & - & - & 15 \\
\hline E. faecium & 4 & - & - & - & - & - & 7.6 & 7 & 6.3 & 20 \\
\hline E. coli ATCC 25922 & - & 6.3 & - & - & - & - & - & - & - & 19 \\
\hline K. pneumoniae & 2.3 & - & 6.6 & 4 & 4 & 4 & - & - & - & 16 \\
\hline L. innocua & 7 & 6.6 & 7 & - & - & - & - & - & - & 16 \\
\hline L. monocytogenes & - & - & - & - & - & - & - & - & - & 23 \\
\hline$P$. aeruginosa DSMZ 50071 & 6 & 2 & 6 & - & - & - & - & - & - & 16 \\
\hline$P$. fluorescens & - & - & - & - & - & - & - & - & - & 13 \\
\hline S. enteritidis ATCC 13075 & 2 & 6.6 & 2 & 14 & 10 & 9.6 & 7 & 6.3 & - & 23 \\
\hline Salmonella infantis & 6.6 & 6.6 & 4.3 & 4.6 & 6 & 4 & - & - & - & 10 \\
\hline S. kentucky & 4 & - & - & - & - & - & - & - & - & 15 \\
\hline S.typhimurium & 6.6 & 6.6 & 7 & - & - & - & - & - & - & 14 \\
\hline S. aureus ATCC 25923 & 7.3 & 6 & 2 & - & - & - & - & - & - & 25 \\
\hline S. epidermidis DSMZ 20044 & 7.3 & 7 & 6.6 & - & - & - & - & - & - & 18 \\
\hline
\end{tabular}

(-): No inhibition.

ATCC: American Type Culture Collection.

DSMZ: German Cell Culture and Microorganism Collection.

TE: Tetracycline

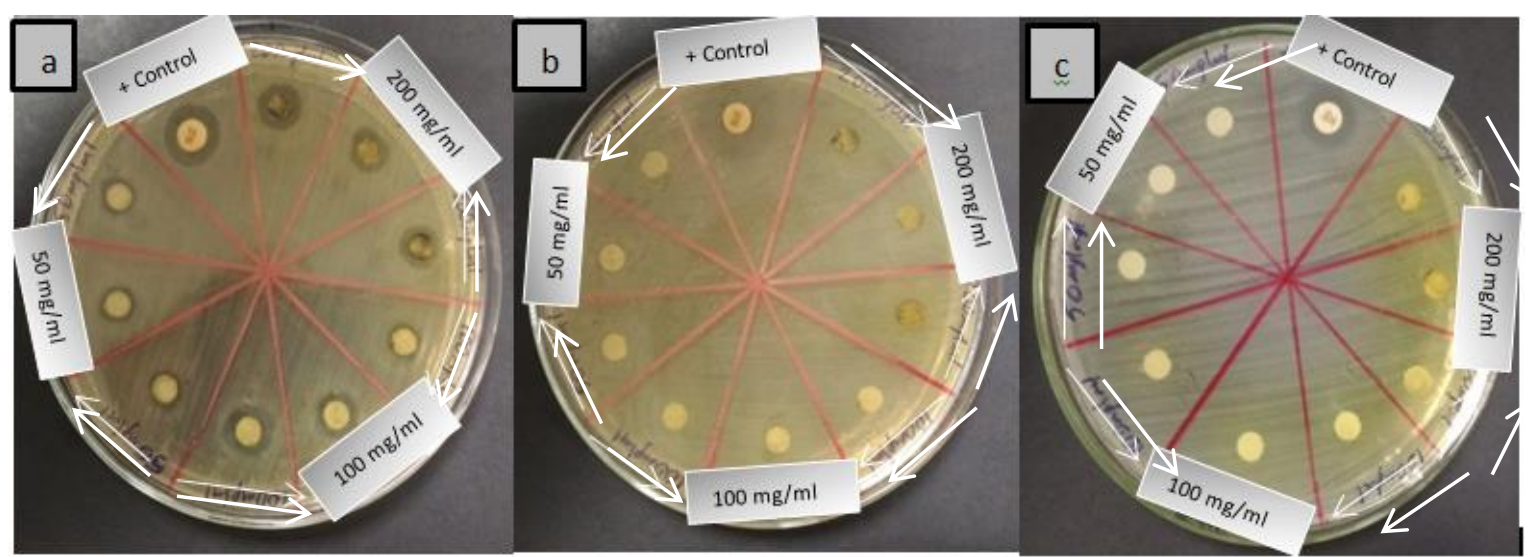

Figure 1. Antimicrobial activities of Alyssum species against the tested microorganisms at concentrations of 200, 100 and $50 \mathrm{mg} / \mathrm{ml}$ (+ Control: Tetracycline (TE 30), a: Effect of A. discolor extract against S. Enteritidis ATCC 13075 strain, b: Effect of A. caricum extract against L. innocua strain, c: Effect of A. sibiricum extract against $\mathrm{S}$. enteritidis ATCC 13075 strain).

Şekil 1. Alyssum türlerinin 200, 100 ve $50 \mathrm{mg} / \mathrm{ml}$ konsantrasyonlarda test edilen mikroorganizmalara karşı antimikrobiyal aktiviteleri (+ Kontrol: Tetrasiklin (TE 30), a: A. discolor ekstresinin S. Enteritidis ATCC 13075 suşuna etkisi, $b: A$. caricum ekstresinin L. innocua suşuna etkisi, $c: A$. sibiricum ekstresinin $S$. enteritidis ATCC 13075 suşuna etkisi). 
Table 3. MIC and MBC results of Alyssum L. species $(\mathrm{mg} / \mathrm{ml})$.

Tablo 3. Alyssum L. türlerinin $M I C$ ve $M B C$ sonuçları $(\mathrm{mg} / \mathrm{ml})$.

\begin{tabular}{lllllll}
\hline Species & Alyssum & Caricum & Alyssum & discolor & \multicolumn{2}{l}{ Alyssum sibiricum } \\
\hline Microorganisms & MIC & MBC & MIC & MBC & MIC & MBC \\
B. subtilis DSMZ 1971 & 100 & 100 & 50 & 100 & 50 & 50 \\
E. aerogenes ATCC 13048 & 100 & 200 & 50 & 100 & 50 & 50 \\
E. durans & 100 & 200 & 50 & 100 & 100 & 200 \\
E. faecalis ATCC 29212 & 100 & 100 & 50 & 100 & 50 & 100 \\
E. faecium & 100 & 200 & 50 & 100 & 100 & 100 \\
E. coli ATCC 25922 & 50 & 100 & 50 & 100 & 50 & 100 \\
K. pneumoniae & 100 & 200 & 50 & 100 & 100 & 100 \\
L. innocua & 100 & 200 & 100 & 100 & 50 & 100 \\
L. monocytogenes & 100 & 200 & 50 & 100 & 50 & 100 \\
P.aeruginosa DSMZ 50071 & 100 & 100 & 50 & 100 & 50 & 200 \\
P. fluorescens & 100 & 200 & 50 & 100 & 100 & 100 \\
S. enteritidis ATCC 13075 & 100 & 200 & 50 & 100 & 50 & 100 \\
S. infantis & 100 & 100 & 50 & 100 & 50 & 100 \\
S. kentucky & 100 & 100 & 50 & 100 & 50 & 100 \\
S. typhimurium & 100 & 100 & 50 & 100 & 50 & 100 \\
S. aureus ATCC 25923 & 100 & 200 & 50 & 100 & 50 & 100 \\
S.epidermidis DSMZ 20044 & 100 & 200 & 50 & 100 & 50 & 100 \\
\hline
\end{tabular}

Table 4. Biofilm inhibition (\%) of Alyssum species.

Tablo 4. Alyssum türlerinin biyofilm inhibisyonu (\%).

\begin{tabular}{|c|c|c|c|c|c|c|c|c|c|}
\hline Species & \multicolumn{3}{|c|}{ Alyssum Caricum } & \multicolumn{3}{|c|}{ Alyssum discolor } & \multicolumn{3}{|c|}{ Alyssum sibiricum } \\
\hline Microorganisms & 200 & 100 & 50 & 200 & 100 & 50 & 200 & 100 & 50 \\
\hline B. subtilis DSMZ 1971 & - & - & - & - & - & - & - & 26.1 & 23.8 \\
\hline E. aerogenes ATCC 13048 & - & - & - & - & - & - & - & - & - \\
\hline E. durans & - & - & - & - & - & - & 15.7 & 46.4 & 37.7 \\
\hline E. faecalis ATCC 29212 & - & - & - & - & - & - & - & 35 & 34 \\
\hline E. faecium & - & - & 12.6 & - & - & - & - & - & - \\
\hline E. coli ATCC 25922 & - & - & - & - & - & - & - & 26.5 & 31.6 \\
\hline K. pneumoniae & - & - & - & - & - & - & - & 38 & 41.5 \\
\hline L. innocua & - & - & - & - & - & - & 14.1 & 31.3 & 36.3 \\
\hline L.monocytogenes & - & - & - & - & - & - & - & - & \\
\hline$P$. aeruginosa DSMZ 50071 & - & - & 12.6 & - & - & - & - & 40.4 & 43.8 \\
\hline P. fluorescens & - & - & - & - & - & - & - & 39.3 & - \\
\hline S. enteritidis ATCC 13075 & - & - & - & - & - & - & 13 & 41.5 & 42.3 \\
\hline S.infantis & - & - & - & - & - & - & 16.3 & 52.4 & 55.3 \\
\hline S.kentucky & - & - & - & - & - & - & - & 24.7 & 24.7 \\
\hline S.typhimurium & - & - & - & - & - & - & 18.1 & 47.5 & 44 \\
\hline S. aureus ATCC 25923 & - & - & - & - & - & - & - & 21.8 & 22.9 \\
\hline S. epidermidis DSMZ 20044 & - & - & - & - & - & - & - & 39.1 & 32.6 \\
\hline
\end{tabular}

(-): No biofilm inhibition

\section{Antioxidant Activity Results}

DPPH Radical Sweeper Activity Determination

Basen on comparative DPPH radical scavenging activities studies in different concentrations of the Alyssum species, three Alyssum species showed close antioxidant activity at the compared concentrations (Figure 1). However, plant extracts found to have lower antioxidant activity when compared with ascorbic acid. Alyssum species generally sweep DPPH radical at 1.56 $\mathrm{mg} / \mathrm{ml}, 3.12 \mathrm{mg} / \mathrm{ml}, 6.25 \mathrm{mg} / \mathrm{ml}$ and $12.5 \mathrm{mg} / \mathrm{ml}$ (Figure 2 ). The best results in all concentrations respectively were; Alyssum caricum > Alyssum sibiricum > Alyssum discolor showed antioxidant activity .

The effective concentration that enables removal of the DPPH radical of $50 \%$ of the studied plant extracts is defined as the $\mathrm{EC}_{50}$ value. The low $\mathrm{EC}_{50}$ value indicates that the antioxidant activity is high. After DPPH removal percent inhibition values of extracts were determined on the chart, $\mathrm{EC}_{50}$ values are shown in Table 5. 


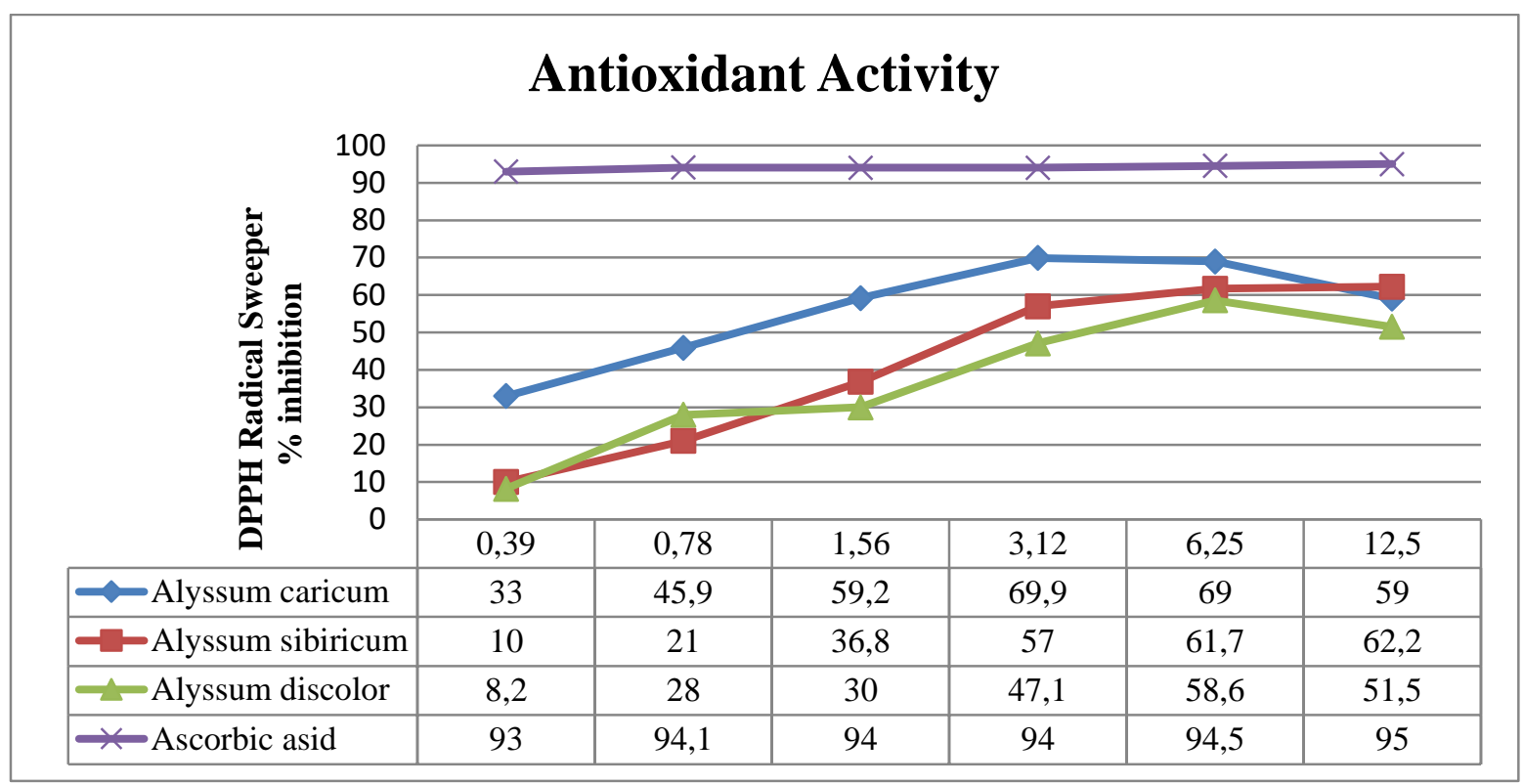

Figure 2. Plant extracts and the activity of the standard substance to sweep the DPPH radical (\%) Şekil 2. Bitki özleri ve standart maddenin DPPH radikalini süpürme etkinliği (\%)

Table 5. Effective concentration (EC50) values obtained from DPPH radical removal results of the studied plant extracts and standard substance.

Tablo 5. Incelenen bitki özütleri ve standart maddenin $D P P H$ radikal giderme sonuçlarından elde edilen etkin konsantrasyon (EC50) değerleri.

\begin{tabular}{ll}
\hline Plant Species & EC $_{50}$ Values \\
\hline A. caricum & 1.08 \\
A.sibiricum & 3.63 \\
A. discolor & 5.72 \\
Ascorbic asid & -- \\
\hline
\end{tabular}

\section{DISCUSSION}

Benli et al. (2007) investigated antimicrobial activities against $E$. faecalis ATCC 29212, B. subtilis, E. coli ATCC 25922, $S$. aureus ATCC 29213, $L$. monocytogenes ATCC $7644, P$. aeruginosa ATCC 27853, C. albicans 845981 strains in their study on six endemic plant species. Alyssum pateri subsp. pateri (seed) extract was observed to show no antimicrobial activity against any strain. Kumar et al. (2017) found that the ethanol and methanol extracts of Camelina sativa (Brassicaceae) which is from the same family as Alyssum L. plant showed a good antimicrobial effect against Trichoderma ressei, Tilletia indica and Phanerochaete chrysosporium strains.

Tozyılmaz and Bülbül (2018), reported their antimicrobial activities against some microorganisms with disc diffusion, MIC and MBC method against methanol extract from Alyssum corsicum and Alyssum caricum plants at $50 \mathrm{mg} / \mathrm{ml}$ concentration and observed that plant extracts showed low activity on microorganisms. A. corsicum extract showed the best effect against Staphylococcus aureus ATCC 25923 and Enterococcus faecium strain, while $A$. caricum extract was showed the best activity against Enterobacter aerogenes ATCC 13048, Enterococcus faecium and Salmonella infantis.

In this study, Alyssum caricum extract showed the best results against Staphylococcus strains. It was determined that the MIC of the extract was $100 \mathrm{mg} / \mathrm{ml}$ against most bacteria and the MBC value was 200 $\mathrm{mg} / \mathrm{ml}$. Although Alyssum discolor ethanol extract showed low activity against $S$. infantis, $K$. pneumoniae and $L$. innocua strains, it was found that it showed good antimicrobial activity against $S$. enteritidis ATCC 13075 strain and also no antimicrobial activity against other microorganisms. It was also observed that the extract had a MIC value of $50 \mathrm{mg} / \mathrm{ml}$ and a MBC value of $100 \mathrm{mg} / \mathrm{ml}$ against most bacteria.

Alyssum sibiricum extract was also unable to show antimicrobial activity against any of the other test bacteria except for Enterococcus faecium and Salmonella enteritidis ATCC 13075 bacterial strains. It was determined that the MIC of the extract was 50 $\mathrm{mg} / \mathrm{ml}$ against most bacteria and the MBC value was $100 \mathrm{mg} / \mathrm{ml}$. Since antimicrobial studies related to some species are not sufficient in the literature, comparison has been made with some antimicrobial studies from family belonging to the species. Accordingly, it was observed that the ethanol extracts used in the studies may vary according to the plant species in antimicrobial activities and the effect level is low. In this study, it was found that the plant extract did not affect most bacteria except for a few bacteria mentioned in the evaluation against bacterial strains. It is believed that the antimicrobial effect of Alyssum 
discolor species will be contributed to the literature by repeating in different solvent or different concentrations.

Antioxidant activity methods are frequently used to purify plants directly or indirectly and to determine their biological effect capacities. Therefore, free radical removing methods such as DPPH and ABTS using determine the total antioxidant effect (Gülçin 2006).

Martinez-Sanchez et al. (2008), reported that Nasturtium officinale plant belonging to Brassicaceae family is high in flavonoid amount, while Diplotaxis tenuifolia (L.) DC. plant high in vitamin C. It was examined that the antioxidant effect of plants with DPPH, FRAP and ABTS methods and polyphenols showed high value in terms of vitamin $\mathrm{C}$ content as a result. Akagün (2009), examined the DPPH radical scavenging activity of Brassica oleracea var. gongylodes (Brassicaceae) plant extract and reported that ethanol extract has antioxidant activity. Consequently, it was determined that ethanol strain.

Extract had $52.4 \%$ radical removal activity at a concentration of $750 \mathrm{\mu g} / \mathrm{ml}$, while was observed $67.5 \%$ activity at a concentration of $1000 \mathrm{\mu g} / \mathrm{ml}$. In this study, Alyssum discolor ethanol extract exhibited the highest DPPH removal activity at $6.25 \mathrm{mg} / \mathrm{ml}$ with $58.6 \%$, and also it was found that the effective concentration (EC50) value was $5.72 \mathrm{mg} / \mathrm{ml}$. Alyssum caricum extract exhibited the highest DPPH removal activity with $69.9 \%$ at $3.12 \mathrm{mg} / \mathrm{ml}$ and it was found that the effective concentration (EC50) value was $1.08 \mathrm{mg} / \mathrm{ml}$. In addition those, Alyssum sibiricum extract exhibited the highest DPPH relieving activity with $62.2 \%$ at a concentration of $6.25 \mathrm{mg} / \mathrm{ml}$ and it was determined that the effective concentration (EC50) value was 3.63 $\mathrm{mg} / \mathrm{ml}$. Also the antioxidant values of all three Alyssum extracts were found to be lower than the standard substance. Due to the lack of sufficient resources about the plant species in the literature, studies regarding the family of the plant have been taken into consideration. The antioxidant activity of ethanol extracts from family-owned plants showed close radical scavenging activity although the ethanol extract of the plants used i at different concentrations in this study. Especially, since the good effect of the Alyssum caricum species compared to the others, it is necessary to carry out studies that support this study with different antioxidant methods.

Biofilm consists one or more microorganisms coming together and organized and materials that absorb the extracellular matrix of the surface they adhere to and the chemicals that form it (Franklin et al., 2015). Biofilms prevent the antibiotics from infecting bacteria and cause microorganisms to be more resistant to antimicrobial agents (Franklin et al., 2015; Oliveira et al., 2016).

Based on the results of the antibiofilm belonging to
Alyssum species, A. caricum extract $E$. faecium and Pseudomonas aeruginosa DSMZ 50071 strains inhibited biofilm by $12.6 \%$, while $A$. sibiricum extract showed antibiofilm activity against most microorganisms, showed the highest biofilm inhibition against 55.3\% Salmonella infantis strain at a concentration of $50 \mathrm{mg} / \mathrm{ml}$. However, it was determined that $A$. discolor plant does not show any biofilm inhibition against test bacteria. The antimicrobial, antibiofilm and antioxidant activities of all plants used in the study were studied for the first time and the literature studies of the families belonging to the species were low. Therefore, it can be said that in this study is an original study.

\section{CONCLUSION}

Recently, there is growing interest in medicinal herbal products due to the resistance of microorganisms against artificial drugs used as antimicrobial and the side effects of artificial drugs are high. It is extremely important to investigate the medical plant components which contain antimicrobial agents. Phenolic compounds in the structure of plants play an important role especially in determining antimicrobial activity. It is important to ensure that the active substance is obtained without damage and the appropriate dosage is used for therapeutic use of plants that are rich in the components they contain. In addition, the use of extracts, which are used in the industry to extend food storage times, is increasing day by day. It is predicted that plant extracts will be used more in many industries, especially in the food industry, because the plants are natural and do not leave residue.

Researchers have focused on researching plants that may have natural antioxidant activity instead of artificial antioxidants in terms of human health. So, studies have started to supplement natural antioxidants to be obtained from plants. In diseases such as cancer, it is increasing that foods containing antioxidants are consumed directly and such extracts are being used as preservatives in the foods we consume.

Some plant extracts have antibiofilm properties as well as antimicrobial activity. Biofilm-forming bacteria show higher antimicrobial resistance than non-biofilmforming bacteria. Biofilm structure bacteria clustering into living or inanimate surfaces as colonies can cause antimicrobial resistance to decrease by extensively producing polymeric components outside the cell. Therefore, in cases where antimicrobial agents are insufficient against biofilm-forming bacteria, new antimicrobial agents and alternative treatment methods are searched. The plants used in the study were shown to have a weak effect in terms of antibiofilm. Plants are thought to can be effective using different solvent and dosage. 


\section{Acknowledgements}

This study was supported by Bartin University Scientific Research Office and the project number is 2017-FEN-CY-015 within the scope of the master's thesis research. We thank Prof Dr Handan UCUN ÖZEL for giving permission to use his laboratory at Bartın University Central Research Laboratory Research and Application Centre.

\section{Conflict of Interests}

Authors declare that there is no conflict of interests.

\section{Author Contribution Rates}

The authors declare that they contribute equally to the article.

\section{REFERENCES}

Akagün G 2009. Alabaş (Brassica oleracea var. gongylodes) bitkisinin antioksidan aktivitesinin incelenmesi. Trakya Üniversitesi Fen Bilimleri Enstitüsü, Biyoloji Ana Bilim Dalı, Yüksek lisans Tezi,106 sy.

Al-Shehbaz IA, Mutlu B, Dönmez AA 2007. The Brassicaceae (Cruciferae) of Turkey, updated. Turkish Journal of Botany, 31: 327-336.

Altuner EM, Çeter T, Gür M, Güney K, Kıran B, Akwieten HE, Soulman SI 2018. Chemical composition and antimicrobial activities of coldpressed oils obtained from nettle, radish and pomegranate seeds. Kastamonu University Journal of Forestry Faculty, 18(3): 236-247.

Altuner EM, Çetin B 2018. Antimicrobial activity of Isothecium alopecuroides and potential effect of some climate elements on the activity of this bryophyte sample. Kastamonu University Journal of Forestry Faculty, 18(2): 126-137.

Atalan E, Bülbül AS, Ceylan Y 2020. Cephalarıa Syriaca (L.): Investigation of antimicrobial, antibiofilm, antioxidant potential and seed morphology. Fresenius Environmental Bulletin, 29(5): 3641-3649.

Avato P, Argentieri MP 2015. Brassicaceae: A rich source of health improving phytochemicals. Phytochemistry Reviews, 14(6): 1019-1033.

Babaoğlu S, Bani B, Açık L, Adıgüzel N 2006. Taxonomic relations among some Turkish serpentine endemic Alyssum (Brassicaceae). Fifth International Balkan Botanical Congress, 20-26 June 2006, Sofia.

Benli M, Bingol U, Geven F, Guney K, Yigit N 2007. An Investigation on the antimicrobial activity of some endemic plant species from Turkey. African Journal of Biotechnology, 7(1) . 1-5.

Blois MS 1958. Antioxidant Determinations by the Use of a Stable Free Radical, Nature, 181(4617): 11991200 .
Bülbül AS, Atalan E, Ulgen H, Ceylan KB 2018. The effect of kombucha fermentation on chestnut cancer factor (Cryphonectria parasitica (Murrill) E.M Barr). Kastamonu University, Journal of Forestry Faculty, 18(3): 304-313.

Bülbül AS, Ceylan Y, Armağan M 2018. Investigation of antibacterial and antifungal properties of Acanthophyllum acerosum and Acanthophyllum microcephalum. Research Journal of Biology Sciences. 11(2): 14-17.

Cartea ME, Francisco M, Soengas P, Velasco P 2011. Phenolic compounds in Brassica vegetables. Molecules 16: 251-280.

Ceyhan N 2008. Klinikte biyofilmlerin önlenmesi için antibiyofilm stratejileri, Infekt, 22: 227-240.

Couvreur TLP, Franzke A, Al-Shehbaz IA, Bakker FT, Koch MA, Mummenhoff K 2010. Molecular phylogenetics, temporal diversification and principles of evolution in the mustard family (Brassicaceae), Molecular Biology and Evolution, 27: 55-71.

Dağcı EK, Dığrak M 2005. Bazı meyve ekstraktlarının antibakteriyal ve antifungal aktiviteleri. KSU. J. Sci. and Eng, 8: 1-8.

Duthie GG, Duthie SJ, Kyle JAM 2000. Plant polyphenols in cancer and heart disease: implications as nutritional antioxidants. Nutrition Research Reviews. 13: 79-106.

Erdogan AE, Everest A 2012. Antimikrobiyal ajan olarak bitki bileşenleri. Türk Bilimsel Derlemeler Dergisi, 6(2): 27-32.

Erdogrul ÖT 2002. Antibacterial activities of some plant extracts used in folk medicine. Pharmaceutical Biology, 40(4): 269-273.

Franklin MJ, Chang C, Akiyama T, Bothner B 2015. New technologies for studying biofilms. Microbiology spectrum, 3(4): 1-32.

Gülçin İ 2006. Antioxidant activity of caffeic acid (3, 4dihydroxycinnamic acid). Toxicology, 217(2-3): 213220.

Huang D, Ou B, Prior RL 2005. The chemistry behind antioxidant capacity assays. Journal of Agricultural and Food Chemistry, 53: 1841-1856.

Iwu GMW, Duncan AB, Okuuji CO 1999. New Antimicrobials of Plant Orijin. ASHS Pres, Alexandria, 457-462

Kokare CR, Chakraborty S, Khobade AN, Mahadik KR 2009. Biofilms: Importance and Applications. Indian J Biotechnology, 8: 159-168.

Kumar K, Gupta SM, Arya MC, Nasim M 2017. In vitro antimicrobial and antioxidant activity of camelina seed extracts as potential source of bioactive compounds. Proceedings of the National Academy of Sciences, India Section B: Biological Sciences, 87(2): 521-526.

March JC, Bentley WE 2004. Quorum sensing and bacterial cross-talk in biotechnology. Curr Opin Biotech, 15(5): 495-502. 
Martinez-Sanchez A, Gil-Izquierdo A, Gil MI, Ferreres F 2008. A comparative study of flavonoid compounds, vitamin $\mathrm{C}$, and antioxidant properties of baby leaf Brassicaceae species. Journal of Agricultural and Food Chemistry, 56(7): 2330-2340.

Mutlu B, Karakuş Ş 2012. A new species of Ornithogalum (Hyacinthaceae) from East Anatolia, Turkey, Turkish Journal of Biology, 36: 125-133.

Oliveira A, Cataneli Pereira V, Pinheiro L, Moraes Riboli DF, Ribeiro de Souza BMK, Cunha M de L 2016. Antimicrobial resistance profile of planktonic and biofilm cells of Staphylococcus aureus and coagulase-negative staphylococci. International Journal of Molecular Sciences. 17 (118): 133-140/ E1423.

Pandey KB, Rizvi SI 2009. Plant polyphenols as dietary antioxidants in human health and disease. Oxidative Medicine and Cellular Longevity. 2: 270278.

Shinji M 1993. Research on antibiotic screening in japan over the last decade: a producing microorganism approach. Actinomycetol. 7: 100106.
Taga ME, Bassler BL 2003. Chemical Communication Among Bacteria. Proc. Natl. Acad. Sci. USA, 100(2): 14549-14554.

Tozyllmaz V, Bulbul AS 2018. Antibacterial effects of Alyssum L. against some gram-positive and gramnegative bacteria, International Symposium Ecology, 19-23 June 2018, Kastamonu.

Tozyılmaz V, Bulbul AS, Ceylan Y, Armagan M 2020. Antibacterial, antifungal, antibiofilm and antioxidant activities of some endemic plants in Anatolian flora. Fresenius Environmental Bulletin, 29(6): 4338-4346.

Ulgen H, Bulbul AS, Ceylan KB 2020. Investigation of antimicrobial, antibiofilm, antioxidant potential and seed morphology of Camelına Satıva L. Crantz. Fresenius Environmental Bulletin, 29(7): 51215129.

Yaldiz G, Kulak M 2014. Assessment on adaptation of some selected medicinal and aromatic plants to the northern parts of Turkey: Agricultural and chemical property based evaluation. Medicinal and Aromatic Plant Research Journal, 2(3): 50-56. 